\title{
Fagfællebedømte artikler
}

\section{Reconstructing the past and the poet: Grundtvig and the Anglo-Saxon Phoenix}

\author{
Lea Grosen Jørgensen
}

In 1840, Grundtvig produced a Danish translation of the Anglo-Saxon poem The Phoenix that reflects some of his ideas concerning history, language, and Anglo-Saxon poetry. The poem also reveals his literary sensibilities as a poet interpreting the past. This article examines Grundtvig's use of metatextual devices in Phenix-Fuglen (1840), with special focus on how Grundtvig employs his poetic sensibilities in the service of Anglo-Saxon scholarship and how he treats the poet as a transhistorical character. The article interprets the translation as a creative response to the medieval text, where the Anglo-Saxon poet and Grundtvig the skald intertwine. Therefore, as this article argues, Phenix-Fuglen is an example of Grundtvig's unique form of medievalism. A new area of interest in Danish literary history studies, medievalism has potential to widen the study of Grundtvig's poetry and the inspiration he drew from medieval history and literature. ${ }^{1}$

Grundtvig was a pioneer in the field of Anglo-Saxon studies. Had he been able to get the support of the English antiquarians of his day, he would

1 This article is a shortened English version of the dissertation "En angelsaksisk skjald: N. F. S. Grundtvigs angelsaksiske forskning 1815-1840 som middelalderisme," delivered May 31 ${ }^{\text {st }}, 2017$ at School of Communication and Culture, Aarhus University. 
have been in charge of a ten-volume series of Old English texts, ${ }^{2}$ which would have formed the basis for the field of Anglo-Saxon literary studies (Bjork 2003, 218). As founding scholarship in the field of Beowulfstudies, Grundtvig's work with Beowulf has overshadowed his study of another masterpiece of Anglo-Saxon poetry, The Phoenix. Much like Beowulf, The Phoenix had a significant influence in Grundtvig's own writing. He translated it into Danish in 1840 under the title Phenix-Fuglen. Et Angelsachsisk Kvad, and he based five of his own poems on The Phoenix (Bjork 2003, 232; Pedersen 2018). The Old English poem is an adaptation of older myths and Latin sources, as Grundtvig remarks in his introduction to the poem. The Anglo-Saxon poet's treatment of the sources inspired Grundtvig, and the poem gave him an opportunity to reflect on his own poetic treatment of medieval texts and language.

This article examines Grundtvig's Phenix-Fuglen from a comparative perspective and considers the work as an example of Grundtvig's unique form of medievalism, the post-medieval reception, adaption, and reinvention of medieval motifs, models, events, and stories. ${ }^{3}$ Medievalism is a useful tool for understanding Grundtvig's literary sensibilities and creative choices as a poet and as a scholar of Anglo-Saxon literature. Based on an analysis of Phenix-Fuglen, I argue that in his translation Grundtvig uses metatextual devices to construct a vision of the Anglo-Saxon past that has

${ }^{2}$ Grundtvig made three scholarly visits to England (1828, 1829, and 1830), where he studied Anglo-Saxon manuscripts. These visits significantly influened his religious and political ideas (Bang 1932; Grell 1992). In the prospectus to Bibliotheca Anglo-Saxonica (1830), Grundtvig presented an idea for a ten-volume series, which he planned to publish with English publishing house Black, Young and Young. In 1831, the Anglo-Saxon Sub-Committee, established by The Society of Antiquarians, published a prospectus similar to Grundtvig's and, as a result, Grundtvig abandoned his own project shortly after his return from England. Nielsen and Toldberg explain the national impulses from the English antiquarians and Grundtvig's own hesitation as reasons that Grundtvig's project failed (Nielsen 2016; Toldberg 1947).

3 The perspective advocated here was inspired in January 2018 with the launch of the research project "Medievalism in Danish Romantic Literature" at Aarhus University, under the supervision of Associate Professor Lis Møller ("Medievalism in Danish Romantic Literature"). For a more thorough introduction to medievalism ans medievalism studies, I refer to Louise D’Arcens (2016) and Berit Kjærullf (2018). 
a double impact. It produces both a scholarly vision and a poetic vision. Both coexist in Phenix-Fuglen, where Grundtvig's study of the poem is determined by his own interpretation and rendition of it and vice versa. Furthermore, he likewise presents his reader with a reinvention of himself as a skald, much akin to the Anglo-Saxon scop (skald) in Old English.

The focus here is on how Grundtvig understood the nature of the poet and, more generally, how he extended his unique literary perspective into his Anglo-Saxon scholarship, which remains underrepresented in Danish literary history. ${ }^{4}$ Recent studies tend to prioritize his hymn production and his ideas about education, nationality, theology, and politics ${ }^{5}$ when, in fact, he was a productive literary scholar. In Digteren Grundtvig (1983), Poul Borum takes note of the absence of scholarship about Grundtvig's literary studies, and Gustav Albeck and Hans Hauge have subsequently taken Borum's argument into consideration (Albeck 1987; Borum 1983; Hauge 2007). None of these authors, however, addresses Grundtvig's Anglo-Saxon scholarship in detail; ${ }^{6}$ rather, they present this part of his authorship as a minor branch of his literary production of hymns and mythological works.

Scholars like Robert E. Bjork, S. A. J. Bradley, Mark Bradshaw Busbee, and Andreas Haarder have drawn attention to Grundtvig's interest in Anglo-Saxon literature and examined the way the medieval period resonates in his ideas of Christianity, history, nationality, and poetics. It is not my intention to discuss Grundtvig's scholarly examinations of Old English poetry directy. The focus is instead on how his medievalism can broaden the discussion about his reuse of medieval literature in creative processes

\footnotetext{
${ }^{4}$ I refer to Gustav Albeck's, Sune Auken's, and Steffen Auring's chapters from the three latest Danish literary histories published by Politiken (1967) and Gyldendal (1989 and 2008). See bibliography for more details.

5 For a list of publications from Grundtvig Selskabet and recent areas of focus at The Grundtvig Center, see http://grundtvigcenteret.au.dk/centeret/samarbejde/ grundtvigselskabet/publikationer/ and http://grundtvigcenteret.au.dk/forskning/ fokusomraade-2017-2019-grundtvig-mellem-foelelse-og-fornuft/.

${ }^{6}$ Borum discusses Phenix-Fuglen in terms of Grundtvig's historical identification and interpretation, but the discussion is only three pages long (Borum 1983, 8385). Albeck briefly mentions Grundtvig's Anglo-Saxon inspiration from Cædmon in "I Kveld blev der banket paa Helvedes Port" (Albeck 1988, 37), whereas Hauge does not mention Grundtvig's Anglo-Saxon scholarship at all.
} 
that produce visions of the Anglo-Saxon past and of himself as a poet, or skald ("skjald").

\section{Phenix-Fuglen}

Included in the tenth-century Exeter Book, the Old English poem The Phoenix is an adaptation of Lactantius' Latin text Carmen de ave Phoenice from approx. the late $3^{\text {rd }}$ century (Grundtvig 1840, 17). ${ }^{7}$ The original Old English poem begins with a description of a forest on top of a hill in the East, an environment similar to Paradise, where the phoenix nests in a palm tree. When the phoenix grows old, it seeks solitude and flies to the desert, surrounded by worshipping birds. In a new forest, the phoenix builds a nest and eventually bursts into flames. From the cinders, a worm emerges, evolves into a bird, grows feathers, and transforms into a new phoenix. When fully grown, the resurrected phoenix returns to its homeland, and people witness its flight before they depict it in stories. References to Genesis and the Book of Job appear as the phoenix builds a new nest, and the poem ends praising Christ after establishing the phoenix's rebirth as a metaphor for Christ's resurrection.

Grundtvig transcribed The Phoenix from the Exeter Book during his third scholarly visit to England in 1831 (Grundtvig 1840, 11). PhenixFuglen was published nine years later and marked, in Grundtvig's own words, the "Sölv-Bryllup" (silver wedding) for his Anglo-Saxon scholarship (Grundtvig 1840, 9), which began with his study of Beowulf in 1815, as a corrective response to Thorkelin's Latin translation of the same poem. Phenix-Fuglen received little attention at the time of its publication, and it has not been reprinted as an independent book since 1840. (It can be read today in digital form on Grundtvigsvarker.dk, published by Vibeke M. Pedersen in April, 2018.) The book seems to have gone unnoticed in Grundtvig studies as well; it is almost unknown outside Denmark (Bjork 2003, 217; Bradley 1999, 142).

Phenix-Fuglen is seventy-one pages long and consists of opening materials, a translation into Danish, and an original poem by Grundtvig.

7 The following summary is based on Craig Williamson's 2017 translation of The Phoenix. 
Grundtvig opens Phenix-Fuglen with a poem dedicated to King Christian VIII, followed by a preface about his Anglo-Saxon studies and introductions to The Phoenix' mythical origin and to the Anglo-Saxon text. The next part consists of the poem in its original Old English language, based on Grundtvig's own transcription. Grundtvig's translation, or "Fri Fordanskning," is located in the second half of the book, accompanied by an additional poem, an echo or "Efterklang," written by Grundtvig. The echo is Grundtvig's personal reflection on the Old English poem. It is an addition to the poem, and though the echo borrows elements from the medieval original, it serves as a response to the Old English poem, not a translation or adaptation per se. Anders Holm has categorized Grundtvig's echo poems as a type of literary genre, where one poem, the echo, relates to another particular poem (Holm 2000, 32). ${ }^{8}$ In this case, the "Efterklang" relates to the Old English Phoenix. From a literary theoretical perspective, Holm's definition corresponds to the term intertextuality; it allows readers to focus attention on the implicit interrelation between different texts.

The introduction, titled "Phenix-Mythen" (1840, 15-22), gives a first insight into Grundtvig's approach. Grundtvig explicitly claims that he interprets the poem's narrative structure-the phoenix' past, aging and rebirth—as images of the three historical phases, "Oldtid" (Ancient times), "Middelalder" (Middle Ages), and "Nyaarstid" (Modern times) (1840, 19). ${ }^{9}$ He believed that the Middle Ages was a stage necessary for the development of the human spirit and that it served as a continuation between the (ancient) past and his own present, or "Nyaarstiden". Grundtvig regarded the Middle Ages as a continuation, and not in opposition, to his own time. This specific theory of universal history affects how Grundtvig approached The Phoenix (Bjork 2003, 222ff).

Pertinent to an investigation of Grundtvig's medievalism is his "Fri Fordanskning" (translation, 44-63) and its relationship to his concept of the "Dansk Efterklang" (Danish echo-poem, 63-71). In both the translation

${ }^{8}$ Holm bases his definition of "efterklang" on the echo poems in Grundtvig's journal Danne-Virke from 1816-1819, which also includes renditions of AngloSaxon literature (e. g. "The Battle of Brunanburh"). Since Grundtvig wrote Phenix-Fuglen twenty years later, his type of echo poem as a genre might have changed.

9 Grundtvig fully explains these terms in his three-volume Haandbog $i$ VerdensHistorien (Handbook of the History of the World, 1833-1843) 
and echo, the poet acts as a metatextual device. In other words, the poet comments on its own interpretation or comments on another text without necessarily quoting the text it comments on (Macksey 1997, xix). Grundtvig's Phenix-Fuglen engages in metatextual discourse, especially at points when the poem comments on the Anglo-Saxon original poem. In one instance, a reference to the art of writing and the adaptation of the phoenix myth is expanded; in another, the metatextual element is deliberately inserted. Both instances call attention to Grundtvig's own acts of translation and adaptation and his own literary disposition towards the AngloSaxon poem. My claim is that Grundtvig responds to the original poem by merging his identity as poet with it. In the original, the Old English poet employs the first-person voice. This poet is not to be confused with the one in Grundtvig's adaptation, where the translator's creative choices and responses to the poem are intentionally and openly included to assert a unique vision of the Anglo-Saxon past. When we encounter the poet in Grundtvig's version, our reading is determined by Grundtvig's interpretation of the Old English poem. Therefore, the Anglo-Saxon poet and the poet Grundtvig in Phenix-Fuglen are both products of Grundtvig's medievalism, in which the past and the present are interconnected through the idea of the poet.

Grundtvig occasionally inserts Nordic and ballad elements in his Danish version of The Phoenix. ${ }^{10}$ For instance, he refers to the phoenix's second nest as "Brattingsborg", a synonym for an unspecified castle that often appears in medieval Danish ballads (Grundtvig 1840, 49; Abrahamsen 1812, 367). When phoenix has been reborn from the flames and flies eastward to his original home, Grundtvig adds another Danish/Nordic context by inserting the term "Rune-Stave" (Rune sticks) in his Danish passage. Here is an example:

${ }^{10}$ For a more detailed interpretation of Grundtvig's use of ballad element, I refer to Vibeke M. Pedersen's introduction to Phenix-Fuglen, published on Grundtvigsvarker.dk in April 2018 (see bibliography). 
ponne wundriað

weras ofer eorðan

wlite and wæstma,

and gewritu cyðað,

mundum mearciað

on mearm-stane,

hwonne se dxg and seo tid

druhtym ge-eawe

frætwe flyht-hwates. ${ }^{11}$

(33, Grundtvig's transcription)
Da Klokke kime, den Dag og Time, med Flid og Iil, man skriver, prænter, paa Pergamenter, med Gyldenstil; ja, dybt indgrave det Rune-Stave i Marmel-Steen ${ }^{12}$ (52)

By combining "Rune Staves" with stone of marble-a material associated with classical antiquity_-Grundtvig synthesizes Nordic and Roman contexts, perhaps to reflect his ambition to increase the Anglo-Saxons' Nordic legacy and their relation to Scandinavia (he expands this claim in his echo poem), as a contrast to Lactantius' Latin version. Nevertheless, he follows the main message that the reborn phoenix is visible to man who chooses to write about his flight and grandeur. The Old English text implicitly says that people have continually told and retold the story of the phoenix - an indication that this poem itself participates in a tradition of storytelling. Grundtvig acknowledges the poem's long tradition in his introduction, as he explains the plot's evolution from Egypt, to Rome, and to AngloSaxon England. Each time the phoenix poem changes hands, the poet reimagines it in a new language and for a new audience. According to Grundtvig, the Anglo-Saxon poet is superior to some of his predecessors, which is why Grundtvig has chosen the Old English text as his source. This could explain why he places the myth in a medieval-sounding context with Norse and ballad allusions, where the phoenix's nest is portrayed as a medieval fortress. Yet it also reveals how he pays attention to the audience. By lending words from ballads and Nordic traditions, Grundtvig dwells on an image of the Middle Ages, one that his contemporary readers

${ }^{11}$ In Williamson's English translation, the passage says: "All men wonder at his shining grace, / And artists rush to catch his splendor / In storied words or shapes of stone- / Each trying to copy the phoenix in flight" (Williamson 2017, 421). 12 "When bells chime, on this day and hour, people write hard and hasty on parchments with golden style; yes, they cut deep the rune staves into stones in marble" (my translation). 
would be well-acquainted with. He makes the poem suitable to Danish readers, thereby adding himself to the list of poets who reimagine the phoenix myth. He distinguishes his poem from former adaptations by looking to the Middle Ages for inspiration and enhancing the medieval context surrounding The Phoenix. The result is that the skald Grundtvig tends to have more in common with a medieval bard or scop, than the modern poet does.

In his introduction, Grundtvig refers to the poet of The Phoenix as "the Anglo-Saxon Skald" (1840, 16ff), and he distinguishes him from clerical writers, claiming that the skald's rendition of the myth is much "warmer" and more "daring." ${ }^{13}$ Grundtvig then explains the Anglo-Saxon symbolic, Christian mindset, with the skald as his point of analysis, before he presents his own interpretation of the poem. It seems that Grundtvig first identifies with the skald, then takes the place of the skald and, following the scop, reinvents the myth in an even more "daring" way. The relationship between the Anglo-Saxon skald and Grundtvig the skald becomes apparent when Grundtvig maintains and develops the poem's metatextual references to itself. For instance, he inserts his historical phase "New Year's time" ("Nyaars-Tid") on page forty-nine. The word reflects Grundtvig's historical interpretation of the poem, as New Year's time is the period in history when the phoenix will be reborn. It creates a tangle of interassociations: New Year's time is the time of Grundtvig; therefore, it suggests that "the phoenix" refers to the bird, to the Old English poem, and to Grundtvig's translation. Later, Grundtvig expands this interpretation by adding a metatextual reference in his Danish version:

13 "men vi vil derimod glæde os over, at denne Forklaring findes endnu langt varmere og dristigere udfört hos den Angel-Sachsiske Skjald en hos Nogen ad Kirke-Fædrene" $(1840,19)$. 


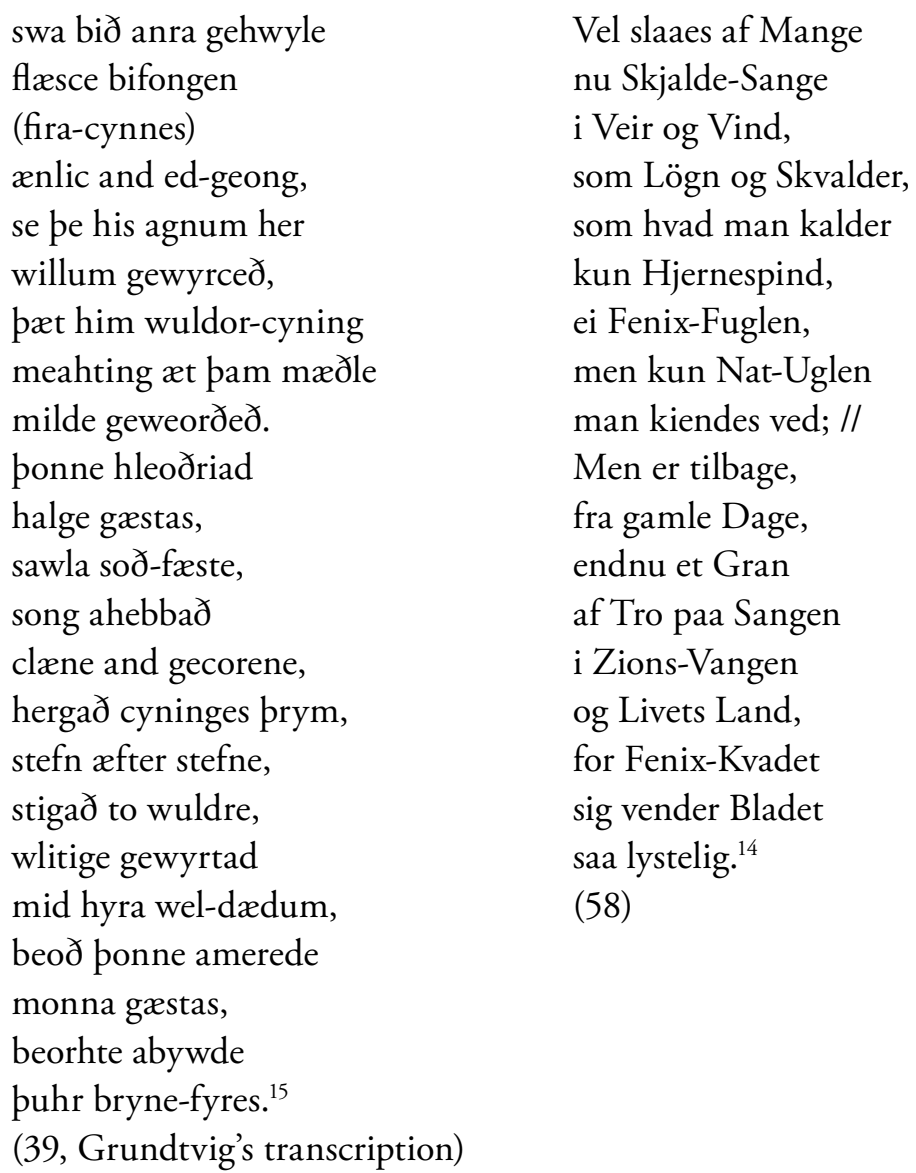

14 "Many believe that common skaldic songs in weather and wind are but lies and traddle, what you would call fabrications, but these people only know the night owl, not the phoenix bird; what remains from the old days is another branch of belief in the song in the field of Zion and the land of life, because the phoenix song turns the page so merrily" (my translation).

15 "So good men and women dressed in flesh, / who follow the faith and work god's will, / shall be young and fair, gloriously rejuvenated, / yearning for the Lord's mercy at that last meeting. / then righteous souls and steadfast spirits / shall raise their holy voices in hymns of praise / to God's glory, strain upon swelling strain. / then they will rise up, wrapped in the fragrance / of god's fullness, the perfume of perfection, / the gift of their goodness, the wonder of their works. / their souls shall be cleansed of all corruption, / separated from sin by the purging flame" (Williamson 2017, 427). 
The first stanza in Grundtvig's Danish version once again makes a reference to the "Phoenix Song" as an example of the truth available within poetry. Skalds do not tell lies, and those who believe that they do only listen to "the Night Owl." By contrast, the phoenix, who flies at dawn and is reborn by fire, represents truth and light. The second stanza elaborates this assumption, as Grundtvig emphasizes the importance of the poem to modern audiences. It stands as a reminder that something remains "from Old Days," even though it is only a "Branch" of the past, in this case, the Anglo-Saxon period. The poem reveals the continuity of Christian belief, from the Middle Ages to the present; it establishes a connection between past and present. In Grundtvig's version, this continuity reinforces the belief in Christ and The Phoenix's central message of resurrection and salvation.

One of the main differences between Grundtvig's translation and the original poem is that Grundtvig has reduced the apocalyptic elements, presented as purification through fire. Most importantly, the original poem does not contain an explicit metatextual reference to itself, in contrast to Grundtvig's poem which includes the "Phoenix Song." While the Old English poem promises salvation, Grundtvig mediates Christian salvation through metatextual references to the poem and his own act of adaptation. These changes allow his Danish version to comment on both the Old English original and the entire Phenix-Fuglen itself. Through his translation, Grundtvig asserts the importance of the skalds and "Skaldic Songs" and of poetic reinvention of ancient texts, which is evident both in the Anglo-Saxon poem and in Grundtvig's adaptation.

The echo poem, Grundtvig's response or relation to The Phoenix, follows his Danish translation and elaborates on the relationship between the Anglo-Saxon scop and Grundtvig the modern skald. The echo poem attempts to unfold the historical importance of Anglo-Saxon poetry in relation to Denmark. According to Grundtvig, the Anglo-Saxons and the Danes both play an important role in the development of the universal, human spirit in the North $(1840,19 \mathrm{ff})$. He argues that Anglo-Saxon poetry proves that a part of the Danish past remained in England. He writes, "When the Mother Tongue / on the Phoenix Pyre / was melted, / a Rob- 
ber's Voice, / a grave only in his own home / recurred at this place."16 Grundtvig here claims that, while Anglo-Saxon poetry was forgotten by the Danes, then and now, Anglo-Saxon literature proves that a part of the Nordic spirit survived outside Denmark. He ends the echo poem by inserting himself as "the Book-Worm." ${ }^{17}$ Later, he transforms (much like the phoenix) and flies to England in order to bring back the Anglo-Saxon poem, but now transformed into a new, Danish version. He wants to recite this Danish translation of The Phoenix to the dying king, ${ }^{18}$ who then discovers "that Christendom / has come in time / in the noble North / and the Phoenix Song / has been reborn anew / in the Danish field." ${ }^{19}$

As in Grundtvig's translation, the phoenix's resurrection transmutes in the resurrection of a medieval poem; both the phoenix and the "Fri Fordanskning" symbolize the greatest resurrection of all - Christ's. Grundtvig dedicates the final pages of Phenix-Fuglen to this literary reconstruction. Mirroring the celebratory "Halleluja" from the original Phoenix, Grundtvig writes how there will be praise and joy in Denmark now that the Anglo-Saxon poem has been reborn from Old English into Danish by Grundtvig himself $(1840,69)$. This statement summarizes the point that Grundtvig has implied in his translation: that he himself has participated in a tradition of skalds, because he has produced a "Skaldic Song" with Phenix-Fuglen. By identifying with the scop, Grundtvig is free to make changes to the original text, based on his own creativity. He presents the Anglo-Saxon past through his own eyes and, as a result, his Phenix-Fuglen exceeds its own pages in more than one way. It presents us with Grundtvig's personal interpretation and relationship to the Anglo-Saxon period and the scop who was born out of this medieval period and who represents it with his own poetry. Meanwhile, the book comments on its own contemporary context, as Grundtvig defends the importance of Anglo-Saxon

16 "Da Moders-Maalet / paa Fenix-Baalet / var smeltet hen, / en Röver-Stemme, / i Grav kun hjemme, / gik her igen” (Grundtvig 1840, 66).

17 "Bog-Ormen" (Grundtvig 1840, 67).

18 Possibly a reference to Frederik VI, who died in 1839. As Grundtvig proclaims, Phenix-Fuglen is a dedication to Frederik VI's successor, Christian VIII, and like with Grundtvig's first encounter with Beowulf in 1815, Phenix-Fuglen marks a coronation year in Denmark $(1840,3,9)$.

19 "for Christendommen / er Timen kommen / i höie Nord, / og Fenix-Sangen / i Dane-Vangen / gienfödt paany” $(1840,67)$. 
poetry in terms of Danish history and the universal Nordic spirit, which will reawake in Denmark. In order to be a part of this reawakening in Phenix-Fuglen, Grundtvig reinvents himself as a poet who takes his place in the skaldic life or "Progeny of Skalds" ${ }^{20}$ and brings forth the light from the past - in this case, the Middle Ages.

\section{Medievalism and the medieval mind of Grundtvig}

Bjork and Bradley deliberate upon Grundtvig's self-image in their study of his Anglo-Saxon scholarship. Bjork's article about Phenix-Fuglen from 2003 offers a descriptive and thorough study of Grundtvig's approach to the Anglo-Saxon poem. According to Bjork, Phenix-Fuglen is the result of Grundtvig's nationalized scholarship, imagination, and philology (Bjork $2003,222,226)$. Bjork focuses on Grundtvig's idea of universal history, in which the individual, the nation, and humanity, all in one, one in all, represent the human spirit. For Grundtvig's Anglo-Saxon poet, the phoenix's resurrection symbolizes the human spirit (221). This spirit also resonates in Grundtvig himself. Bjork explains (231),

With a lyrical flourish, Phenix-Fuglen ends as more than a mere edition of an Old English poem and Grundtvig as more than a mere scholarly editor. He actually becomes the phoenix in the course of the book, and the book becomes an embodiment of a coherent view of history and the place of the Anglo-Saxons and the Danes within it even as it celebrates a new era of the spirit in Denmark.

The different parts of Phenix-Fuglen follow Grundtvig's interpretation of the phoenix-myth. The translation itself therefore symbolizes the rebirth of the Phoenix. Through Grundtvig's editing and translation, the Old English poem is now reborn from its own ashes (Bjork, 226).

While Bjork is correct, it must be noted that Phenix-Fuglen also expresses Grundtvig's personal contemplation on the acts of editing, translating, and adapting medieval texts. Grundtvig explicitly adds metatextual devices in his Danish version, and he thereby shifts the focus from the

20 “Skjalde-Kuld” (1840, 67). 
phoenix's mythical-Christian importance to the Anglo-Saxon poem itself. Much like the phoenix itself, the poem is reborn in the hands of Grundtvig, the modern skald. The poem represents continuity, yet also change. As Grundtvig insists on adding new material to the original poem, he defends his own status as a skald who follows the scop's example and relies on his own creativity. Bjork writes that Grundtvig's rendition is "necessarily loose, to be sure, and perhaps sentimental, but it is hardly meaningless" (228). There is little doubt that Grundtvig's translation facilitates his interpretation of the phoenix myth. This point, however, requires development, and Grundtvig's translation is where it can be found. Much like the echo poem, the translation expresses Grundtvig's creative response to the original poem. This does not come into conflict with his scholarly effort. Rather, it reveals that his scholarly and literary approach to the Old English poem are intertwined and can be read in continuation of each other. In both his translation and echo poem, he deliberately alters the source material and simultaneously adds something new.

That something new is how Grundtvig's medievalism through creative translation serves as a scholarly effort. His translation bridges a gap between medievalism and medieval studies, a gap that varies over time and is sometimes nonexistent, according to medievalism scholars. Louise D'Arcens writes that the difference between the study of the "found" Middle Ages (i.e. medieval studies) and the study of the "made" Middle Ages (medievalism) is problematic, because "the creative responses to medieval remnants and artefacts have existed abidingly alongside scholarly responses" (D’Arcens 2016, 3). Matthews takes D’Arcens' assumption a step further, claiming that medievalism is and always has been a part of medieval studies, because "[t]he very idea of the Middle Ages produces medievalism" (Matthews 2017, 118). He also takes the act of translation into consideration with Beowulf as an example. He writes, "Any edition or translation of Beowulf is a postmedieval artefact; it cannot be anything else" (168). For Matthews, this concept especially applies to the Romantic period, where authors like Percy and Ritson took liberties in their editing process and choice of translation. ${ }^{21}$ Grundtvig might as well be added to

21 Matthews notes, however, that it is a retrospective judgement to consider their work as medievalism, because their work does not live up to modern scholarly standards. These examples of translation further problematize the distinction between medievalism and medieval studies (172). 
this list, because of his creativity as a translator and editor - something that displeased some of his contemporaries like Rasmus Rask (Christoffersen, 1947, 32).

Bjork and Bradley also recognize the quality and liberty in Grundtvig's translation. Bjork remarks that Grundtvig partly expands, partly contracts the Old English text in his Danish version and, though the transcription itself contains misreadings and errors, Bjork adds that Grundtvig's edition remains impressive (Bjork 2003, 219ff). He writes that Grundtvig's poetic form is the plumage of the risen phoenix, whereas the bird inwardly - the essential narrative of the original poem-remains the same (226-227). Bradley similarly describes Grundtvig's translation as a recast, or "genstøbning" in Danish, meaning that he invents new words out of the Old English language (Bradley 2000, 38ff; Bradley 2002, 161ff). He thereby brings an extra dimension to Anglo-Saxon literature, while at the same time adopting Anglo-Saxon metaphors and images into his own phenomenology (Bradley 1996, 105ff). Neither Bjork nor Bradley employ the term "medievalism," but their presentations of Grundtvig's translation as a 'recast' and an expansion of the original poem suggest that Grundtvig's vocabulary consists of an exchange between Old English and modern Danish, between the past and the present. In this aspect, it is sufficient to regard Grundtvig as the co-author of The Phoenix rather than its translator. This authority gives him the opportunity to reinterpret and even reconstruct the Anglo-Saxon poem in his own fashion and with his own words. Phenix-Fuglen therefore is of special interest to scholars of Anglo-Saxon literature (like Bjork and Bradley), but also to scholars in medievalism. What should be further stressed is Grundtvig's creative treatment of medieval poetry. Instead of reading his translation of The Phoenix as a continuation of the original poem, we should also analyze Grundtvig's adaptation as a manifestation of his medievalism, thereby making his Anglo-Saxon scholarship more accessible for comparative, literary approaches.

Bjork and Bradley also discuss Grundtvig's translation in regard to his own idea of the Anglo-Saxon poet and his own poetic function. Bjork notes that Grundtvig's introduction, translation, and reflection reverberate in his echo poem. Bjork also mentions the "book-worm" in the final part of Phenix-Fuglen, where Grundtvig condemns the Roman influence and Latin language, and in return praises the Danish mother tongue (Bjork 
2003, 228-229). While Bjork reads Grundtvig's self-image as a transformation, where he himself turns into a phoenix, this transformation might also be regarded as an example of how Grundtvig himself emerges within the poem and thereby recreates himself - not as a phoenix, but as a skald flying with a "Wing of Skaldhood." $22 \mathrm{He}$ is a skald who revives the past through his own imagination and poetic daring. In this sense, Phenix-Fuglen is a poem about Grundtvig's literary sensibility and attitude towards the poet's choices and reasons for adapting medieval poetry. He uses the myth of the phoenix to defend his translation as an act of recreation. In addition, he succeeds in recreating himself as a skald who takes a "Branch" of the past and presents it in a new light for a modern, Danish audience. Grundtvig's theory of universal history overshadows this element of poetic reflection within his Anglo-Saxon scholarship. According to Bjork, the "book-worm" Grundtvig is the same as the author Grundtvig. Though it is clear that Grundtvig bases his interpretation of Phenix-Fuglen on his own historical mindset, the metatextual elements within the text itself should not be overlooked. Without attention to those elements, the medievalism, that is, the reinvention of the Middle Ages, that Grundtvig displays in Phenix-Fuglen, particularly in the Danish translation, might also be missed. Both the poet Grundtvig and the scop are products of Grundtvig's inspiration and adaptation of a medieval source. They both illustrate his ambition to bring a part of the Anglo-Saxon past back to life. In order to do this, he must recreate himself within the text, thereby establishing a relationship with the Middle Ages and reinventing a medieval poem for a modern readership.

In his discussion of Grundtvig's poetic self-image, Bradley writes that Grundtvig regards the poet as someone who seeks to understand ancient poetry (Bradley 1996, 99) - a characteristic especially applying to Grundtvig himself. When studying Anglo-Saxon literature, Grundtvig took special notice of poets like Cædmon and Widsith, who, according to Bradley, became role models for Grundtvig, who saw himself as their skaldic heir (Bradley 1999, 152; Bradley 2004, 7). The Anglo-Saxon poet or scop has a special place in Grundtvig's mindset, because the scop's poems are in the vernacular language, the language of the people. Much like the scop, Grundtvig himself seeks "the role of prophet and teacher of folkelighed and

22 "Skjaldskabs Vinge" (1840, 69). 
the folkeaand among the latter-day custodians of the spirit of the ancient North, the Danish people" (Bradley 1999, 142). Bradley also notes that Grundtvig thereby reflects the search for artistic self-identity during the Romantic period, yet he adds that Grundtvig alters the common Romantic idea of the poetic genius. To Grundtvig, the community united by the shared mother tongue always supersedes the individual poet; therefore, he writes to the public reader rather than a specific community of scholars or poets (Bradley 1999, 143ff; Bradley 1993, 58ff).

In conclusion, the relationship between the Anglo-Saxon scop and Grundtvig must be regarded as a central element in Phenix-Fuglen: it illustrates Grundtvig's admiration for Anglo-Saxon literature and his response to it, as a modern heir to the scops. Too often, scholars do not necessarily distinguish Grundtvig from the self-image he produces in his authorship. Some draw attention to how Grundtvig appropriated Anglo-Saxon literature, but they fail to question to which extend this appropriation is a construction of the past. Others admire Grundtvig's Anglo-Saxon scholarship, but they measure his studies in terms of his entire authorship and Anglo-Saxon studies in general. I have attempted to analyze parts of Phenix-Fuglen to establish the entire poem as an individual literary work, in which a unique, valuable form of medievalism manifests itself. It is no doubt fruitful to read Phenix-Fuglen as a continuation of Grundtvig's theories about Christianity, theology, and nationality, but it is perhaps equally rewarding to compare his Anglo-Saxon scholarship with the forms of medievalism employed by his contemporaries. Furthermore, Grundtvig's emphasis on the Anglo-Saxon poet and his self-position as a timeless poet reveals literary self-awareness within The Phoenix itself. Grundtvig reinforces these elements in his Danish version to such an extent that he becomes part of the Anglo-Saxon period that he reconstructs and responds to as a poet. A study of the literary sensibility in Phenix-Fuglen, as a work of medievalism, may perhaps reveal similar metatextual devices in The Phoenix, a poem which likewise reshapes and reimagines a piece of text from the past. 


\section{Bibliography}

\section{Works by Grundtvig}

Grundtvig, N.F.S. (1840), Phenix-Fuglen. Et angelsachsisk Kvad, København, Fabritius de Tengnagel.

„Publikationer“ from the Grundtvig Center's website, http://grundtvigcenteret. au.dk/centeret/samarbejde/grundtvigselskabet/publikationer/ (03.12.2018).

"Fokusområde 2017-2019: Grundtvig - mellem følelse og fornuft" from The Grundtvig Center's website, http://grundtvigcenteret.au.dk/forskning/fokusomraade-2017-2019-grundtvig-mellem-foelelse-og-fornuft/ (03.12.2018).

"Medievalism in Danish Romantic Literature" from Aarhus University's website, http://projekter.au.dk/en/medievalism-in-danish-romantic-literature/ (03.12.2018).

Abrahamsen, Werbet et al. (1812), Udvalgte Danske Viser fra Middelalderen efter A. S. Vedels og P. Syvs trykte Udgaver og efter haandskrevne Samlinger udgivne paa ny af Abrahamsen, Nyerup og Rabbek. 1ste del, København, J.F. Schultz.

Albeck, Gustav (1967), “N. F. S. Grundtvig. Den bogglade Dreng i Præstens Bibliotek" in Gustav Albeck et al., Dansk Litteratur Historie bind 2: Fra Oehlenschläger til Kierkegaard, Politikens Forlag, 116-171.

Albeck, Gustav (1987), "Har Grundtvig-Selskabet forsømt Digteren Grundtvig?” in Grundtvig-Studier 1987, 29-44.

Auken, Sune (2008), "Nordisk mytologi og salmedigtning - N. F. S. Grundtvig" in Klaus P. Mortensen \& May Schack (ed.), Dansk litteraturs historie - bd. 2: 1800-1870, København, Gyldendal, 199-237.

Auring, Steffen et al. (1984), Dansk litteraturhistorie 5: Borgerlig enhedskultur 1807-48, København, Gyldendal.

Bang, J. P. (1932), Grundtvig og England: Studier over Grundtvig, København, Kirkeligt Samfunds Forlag.

Bjork, Robert E. (2003), "N. F. S. Grundtvig's Edition of the Old English Phoenix: A Vision of a Vision of Paradise" in Mark C. Amodio \& Katherine O'Brien O'Keeffe (ed.), Unlocking the Wordhord: Anglo-Saxon Studies in Memory of Edward B. Irwing, Jr., University of Toronto Press, 217-239. 
Borum, Poul (1983), Digteren Grundtvig, København, Gyldendal.

Bradley, S. A. J. (1993), ““The First New-European Literature”: N. F. S. Grundtvig's Reception of Anglo-Saxon Literature" in A. M. Allchin et al. (ed.), Heritage and Prophecy: Grundtvig and the English-Speaking World, Aarhus University Press, 45-72.

Bradley, S. A. J. (1996), ““Stridige Stykker jeg snildt forbandt”: Grundtvig's creative synthesis of Anglo-Saxon sources” in Grundtvig-Studier 1996, 97-127.

Bradley, S. A. J. (1999), “The Recovery of England's "skrinlagt fortid” - a progressive Report” in Grundtvig-Studier 1999, 138-161.

Bradley, S. A. J. (2000), "Det er hvad jeg kalder at oversætte Digte: Grundtvig as translator" in Grundtvig-Studier 2000, 36-59.

Bradley, S. A. J. (2002), "Grundtvig's Land of the Living and Anglo-Saxon scholarship in the Royal Library of Copenhagen" in Gundtvig-Studier 2002, 157183.

Bradley, S. A. J. (2004), "Before Irenaeus: The Making of Grundtvig the Medievalist” in Grundtvig-Studier 2004, 234-254.

Busbee, Mark Bradshaw (2012), “The First Complete Translation of Beowulfinto a Modern Language" in Jane Beal \& Mark Bradshaw Busbee (ed.), Translating the Past: Essays on Medieval Literature in Honor of Marijane Osborn, Tempe, ACMRS, 37-58.

Christoffersen, Jens (1947), "Hvorledes Beowulf kom til Danmark. G. J. Thorkelin, Johan Bülow og N. F. S. Grundtvig" in Bogvennen. Aarbog for Bogkunst og Boghistorie, 19-32.

D'Arcens, Louise (2016), "Introduction” in Louise D’Arcens (ed.), The Cambridge Companion to Medievalism, Cambridge University Press, 1-13.

Grell, Helge (1992), England og Grundtvig, Aarhus Universitetsforlag.

Haarder, Andreas (1983), "Grundtvig og den oldnordiske kulturarv" in Christian Thodberg \& Anders Pontoppidan Thyssen (ed.), Grundtvig og grundtvigianismen $i$ nyt lys, Aarhus: ANIS \& Det danske Selskab, 70-83.

Hauge, Hans (2009), "Alt-i-alt: Et gensyn med Poul Borums syn på Digteren Grundtvig" in Grundtvig-Studier 2009, 188-202.

Holm, Anders (2000), Historie og efterklang. En studie i N.F.S. Grundtvigs tidsskrift Danne-Virke, Odense, Odense Universitetsforlag.

Kjærulff, Berit (2018), "Medievalism and the Post-Medieval Middle Ages: A Review of Anglophone Medievalism Studies” in Orbis Litterarum, vol. 74, no. 5, 458-470. 
Macksey, Richard (1997), "Foreword" in Gérard Genette, Paratexts. Tresholds of interpretation, Cambridge, Cambridge University Press, xi-xxii.

Matthews, David (2017/2015), Medievalism. A Critical History, Cambridge, D. S. Brewer.

Nielsen, Klaus (2014), "Indledning" to Bibliotheca Anglo-Saxonica. Prospectus, and Proposals of a Subscription, for the Publication of the Most Valuable Anglo-Saxon Manuscripts, Illustrative of the Early Poetry and Literature of Our Language. Most of Which Have Never Yet Been Printed, published online on Grundtvigsvarker.dk, http://www.xn--grundtvigsvrker-7lb.dk/tekstvisning/3655/0\#\{\%2 20\%22:0,\%22v0\%22:0,\%22k\%22:0\} (03.12.2018).

Pedersen, Vibeke A. (2015), "Indledning" to "Et Par Ord om det nys udkomne angelsaxiske digt" og "Nok et Par Ord om Bjovulfs Drape", published online on Grundtvigsverker.dk, http://www.xn--grundtvigsvrker-7lb.dk/tekstvisning /6984/0\#\{\%220\%22:0,\%22v0\%22:0,\%22k\%22:0\} (03.12.2018).

Pedersen, Vibeke A. (2018), ““Indledning” to "Fugl Phønix””, Phenix-Fuglen. Et Angelsachsisk Kvad förstegang udgivet med Indledning, Fordanskning og Efterklang og "Phenix-Fuglen", published online on Grundtvigsvarker.dk, http:// www.xn--grundtvigsvrker-7lb.dk/tekstvisning/16840/0\#\{\%220\%22:0,\%22v 0\%22:0,\%22k\%22:0\} (03.12.18)

Williamson, Craig (translator, 2017), The Complete Old English Poems, Philadelphia, University of Pennsylvania Press. 